\title{
Exploration on the Reform and Innovation of Teaching Supervision in the Local Application Universities
}

\author{
Xiaoping Wang, Xiaoming Li , Jiaming Zhong, Naizhu Huang*(corresponding author) \\ Xiangnan University, Hunan, Chenzhou, 423000 \\ xnupaper@163.com \\ * Corresponding Author
}

\begin{abstract}
Teaching supervision are endued three major functions of supervising teacher and student and administration in the local colleges and universities, including school's philosophy and positioning, personnel training programs, curriculum, teaching content, teaching level, teaching management, student learning situation, teaching equipment and fund, campus environment and culture. At present, the local colleges and universities are faced with the arduous task of transforming to the applied technology university. If teaching supervision as the teaching supervision system plays a leading function of various disciplines and professions orientation to the application technology university, It will be reformed and innovated teaching supervision concept, system, methods, team building in order to meet the needs of application oriented personnel training.
\end{abstract}

Keywords-Teaching supervision; Local colleges and universities; Applied university; Reform and innovation.

\section{INTRODUCTION}

Local colleges and universities refer to common higher institutions in provinces, autonomous regions and municipalities directly under the central government, which are supported by local finance. Their target is to serve the development of regional economy and society so as to cultivate high-quality applied talents suitable for regional development. Transition and development of local colleges and universities should rely on comprehensive reforms of school-running system, professional construction, curriculum provision, teaching management, teaching staff building, management service ode and students' evaluation on teaching quality so as to establish a cultivation system of applied talents, which can make contributions to regional economic and social development.Educational supervision, an important part of modern education in terms of administrative management, plays an significant role in guiding school-running orientation, promoting school-running level and improving educational quality. Since the 1990s, due to the mass expansion of colleges and universities, there has been a serious shortage of teaching resources. So in order to enhance the supervision on teaching quality, educational supervision, which plays an important role in primary and secondary education, has been introduced to colleges and universities, and now it has been recalled as teaching supervision. It is no doubt an important reforming measure to effectively implement teaching supervision in local colleges and universities, which will greatly standardize teaching management in colleges and universities, strengthen teachers' responsibility for teaching, improve teaching methods and promote teaching quality. However, with the transition and development of local colleges and universities into applied-technological universities, the original concept, system, methods and team building have been unsuitable for current applied talent cultivation mode, requiring urgent reform and innovation.

\section{CONCEPT PRIORITY: MOTIVE POWER OF THE}

TEACHING SUPERVISION REFORM IN LOCAL COLLEGES

\section{AND UNIVERSITIES}

\section{A. Focus on connotation construction and lead the school transition with developmental concept}

In today's information age, Internet + has been applied to all fields of social life; while the new higher educational structure and talent cultivation mode resulted by higher education popularization can't meet the need of economic transition, industrial upgrading and innovation drive. According to the requirements in Outlines of National Middle and Long-term Educational Reform and Development Plans, higher education should meet the need of national and regional economic and social development, establish dynamic adjustment mechanism, constantly optimize the structure of higher education and subject majors, types and hierarchical structure with good combination of multiple subjects; and meanwhile more emphasis should be placed on enlarging the cultivation scale of applied, comprehensive and professional talents. By adhering to these demands, local colleges and universities should have an appropriate school-running concept, aiming to establish applied-technological universities with fine quality and characteristic. At present, the cultivation proportion of applied-technique-oriented professionals and academic talents is 8 to 2 in European developed countries, which is corresponding to the social economic development; while applied technique-oriented universities are important institutes for cultivating such kind of talents. In general, the applied technique-oriented universities have the following characteristics. Guided by the concepts and principles of 
establishing applied discipline system and developing applied scientific research, the applied technique-oriented universities serve regional industries and social economic development, aiming to cultivate applied talents with newly emerging majors or new cultivation-orientation as the main parts. Their curriculum design is mainly about discipline and application, which are two independent systems on construction and application cultivation respectively. The teaching method is a new method combining discipline teaching method and applied teaching method together. The teaching staff possesses a fine quality of applied capabilities. The fundamental means of cultivating applied talents is to combine industry, study and research together. The major action to accelerate the construction of applied universities is to abide by international standards. Teaching supervision in local colleges and universities should follow the basic features of applied technique-oriented universities with more attention on connotation construction, scale standardization, structure optimization, characteristic enhancement, innovation strengthening as well as quality promotion. The transition work in schools and colleges should be supervised, inspected, evaluated and guided with a developmental concept. For example, according to the demand of applied talents, professional system and discipline system should be established with formation of talent cultivation scheme, implementation of talent cultivation mode reformation and establishment double-type teaching staff. Meanwhile, an integrated talent cultivation system of industry, study and research should be established by implementing education and educational reform.

\section{B. It will be good for decision-making among school}

\section{top leaders by delivering supervision materials \\ objectively, fairly and responsibly with more}

\section{attention on supervision process.}

The key sections of teaching quality assurance system in local colleges and universities are teaching operation and teaching monitoring; while teaching supervision, as the main part of teaching monitoring, should certainly pay attention to problems in school education and teaching process so as to provide basic materials for schools regarding decision making. Stufflebeam, an American scholar, once said that the main purpose of evaluation is not to prove but to improve. That is to say, evaluation is not a negative behavior with the main purpose of punishment, but is a positive behavior aiming to improve work friendly and cooperatively. The core elements of teaching supervision is inspection and evaluation, so it should be practical and realistic with deep investigation and accumulation of first-hand materials so as to reflect specific problems objectively and fairly during school educational process, such as problems during the formation and execution of talent cultivation schemes, problems in the reform of talent cultivation mode, problems in the establishment of double-type teaching staff, problems in the cooperative education of industry, study and research, problems in discipline provision and subject construction as well as problems in the reform of teaching methods and class teaching, and so on.

\section{INSTITUTIONAL GUARANTEE: THE PUSHER OF}

\section{TEACHING SUPERVISION REFORM IN LOCAL COLLEGES}

\section{AND UNIVERSITIES}

Educational supervision system is an indispensable part of modern educational system. It is an important symbol to measure the educational and administrative level in a country, a region or in a school. A perfect and sound supervision system in a college or university is a strong measure to improve teaching quality and realize educational goals; and meanwhile it is also a necessary way to achieve sound and healthy development for educational work. By far, teaching supervision institutions have been set up by most local colleges and universities, but they can't be given into full play due to the lack of attention and guarantee scheme. Sometimes they can even be marginalized. Generally speaking, teaching supervision in local colleges and universities include teaching supervision, study supervision and management supervision, and its contents cover school-running concept and orientation, talent cultivation scheme, curriculum provision, teaching contents, teaching level, teaching management, students' learning condition, teaching equipment and expenditure, campus environment and culture and so on; however, in reality, during the implementation of supervision work in most colleges and universities, schools usually narrow the supervision scope. They pay more attention to supervise the quality of teaching but with less exploration and construction on study supervision and management supervision. Therefore, reform and innovation of teaching supervision in applied local colleges and universities should first realize the importance of school teaching supervision with much support. Administrative management in contemporary universities should be an educational administrative management system combined with educational decision-making system, execution system and supervision system all together, during which school leaders should fully affirm the role and function of teaching supervision in monitoring system with formation of earnest and practical supervision policies and guarantee measures so as to create beneficiary conditions for implementing supervision work independently and authoritatively. Second, an effective operation scheme should be established for teaching supervision in colleges and universities. On one hand, a rational educational supervision system should be set. Teaching supervision institution in local colleges and universities is a department in school administrative management, which is a comparatively independent and authoritative organization consisting of teaching inspection team, students' information inspectors and various evaluation experts under the direct leadership of school headmaster. On the other hand, relative policies and principles should be formulated to provide systematic guarantee for teaching supervision work since teaching supervision work can be affected by unimportant factors without systematic guarantee, and thus it may lead to ineffective management supervision 
and study supervision. Besides, working system of teaching supervision should be formulated, mainly including supervision process, supervision evaluation system, post responsibility system, management of inspection documents, training system of inspectors and working rules for standardizing inspectors' behaviors. Fourth, establishment of teaching supervision team should be strengthened since rational structure of teaching supervision team and sound personnel qualities are important guarantees for successful implementation of teaching supervision work. Therefore, local colleges and universities should formulate a rational selection scheme for selection supervisors and build a both professional and occupational supervision team by legal procedure. The full-time staff can be selected from excellent on-job administrators and teachers with a number of 3 to five; while the part-time staff can be fair, healthy and warmhearted retired teachers of fine ideological qualities and rich experience in teaching and research with an amount of 10 to 12 . Colleges and universities also need to establish expert database with the implementation of term responsibility system for full-time and part-time staff so that their responsibilities can be defined with the endowment of complete power, and thus they can carry out supervision work independently according to rules and principles. Fifth, the feedback scheme of teaching supervision should be enhanced since the final goal of teaching supervision is to improve teaching. Without feedback or timely feedback, problems during the supervision can be delayed or worsened. As for the problems in the feedback, they should be reported to upper leaders with proposal of corresponding improvement plans.

\section{METHOD INNOVATION-INNOVATION POINT OF}

\section{TEACHING SUPER VISION REFORM IN LOCAL COLLEGES}

\section{AND UNIVERSITIES}

In order to give full play to teaching supervision during the transition and development of local colleges and universities, schools should innovate and reform the methods of teaching supervision. The original teaching supervision methods in local colleges and universities is in-class inspection, the main point of teaching, which plays an important role in improving teaching and curriculum design and motivate students to have positive and active study. However, it must be too simple to adopt in-class inspection only because teaching supervision includes teaching supervision, study supervision and management supervision. Thus, besides in-class inspection, field inspection, lecture and deep interview of administrators, reference of teaching and management should also be employed for reforming and innovating teaching supervision so as to find universal problems with timely feedback by mastering first-hand materials comprehensively.

Field investigation means that teaching inspectors carry out orderly and purposeful investigation on teaching sites, laboratories, practice base and industry-study-research base guided by related staff so as to acquire accurate information about teaching work in the school. First, the investigation object and goal of should be clarified for sure in order to avoid randomness and blindness; besides, both the whole situation and partial condition should be investigated so as to better understand the total thing; meanwhile, while investigating the field situation, some notes and analysis should be made so as to provide precise information for final investigation report. Forum is a qualitative research method, by which teaching supervisors can invite 6 to 10 teachers of student groups to have a round-table conference on a certain subject so as to discover some valuable information. To have a symposium, teaching supervisors should master basic questioning skills, leading teachers or students to deeply explore the essence and core of the problems gradually instead of discussing one thing for a long time; meanwhile they should learn to listen to others so as to understand the true ideas of speakers regardless of superficial meaning or hidden meaning. By this way, the following discussion can be implemented based on full understanding of each other. The symposium is usually carried out in the form of tea party, and it lasts from 30 minutes to 2 hours. As for the questionnaire, it is kind of research method employed by teaching supervisors with the designed papers so as to know collect information or seek suggestions from investigation objects. The questions they want to investigate can be put in a form and emailed to investigation objects, or supervisors can ask teachers or students face to face to know about their opinions and suggestions. The key points of employing questionnaire are preparation of questionnaire, selection of objects and analysis of results. However, deep interview is an unorganized, direct and personal interview method adopted by teaching supervisors, aiming to reveal the potential motivation, belief, attitude and feelings of one particular problem, which can be used for explore the object's deep understanding of the problem. During the process of deep interview, the investigator and the object can exchange information freely so as to deeply explore the interviewee's inner mind, which is suitable for complicated and abstract problems. Referring to materials means deep supervision on teaching system, meeting records, statistical statement, students' papers and homework, graduates' papers and designs, experimental reports, teaching journals and teaching plans by teaching supervisors, which aims to discover problems during the cultivation of applied talents with proposal of suggestions and improvement methods.

\section{TEAm BUILDING- THE KEY POINT OF TEACHING}

\section{SUPERVISION REFORM IN LOCAL COLLEGES AND}

\section{UNIVERSITIES}

The quality of teaching supervision team is especially important for the effective implementation of teaching supervision in local colleges and universities. The supervisors are not only responsible for supervising the teaching and discovering problems, but they also need to guide teachers or students to solve the problems. In Western countries, they have strict requirements for the supervisors' degree, experience, majors and ages. For example, In all states of America, supervisors are required to have bachelor degree or master degree with 2 to 10 years' working experience in teaching or 
supervision. Some states even require full-time supervisors to hold certificates with study experience in educational administration, educational supervision, educational psychology, educational measurement and evaluation as well as teaching methods but low demand for ages. According to a sample survey, most American teaching supervisors have certain experience in teaching with an average teaching age of 7.4 years, and their average age is 38 years old, among whom $15.4 \%$ are doctors and $65.7 \%$ are masters. Besides, they are enthusiastic, friendly, out-going and good at communication with quite good patience and sense of humor. They are ready to devote to education and they do well in persuade others. They constantly make improvements for school work with good ideas and creation of democratic working environment. They can get along well with teachers so that teachers can improve their teaching voluntarily.

In order to strengthen the construction of teaching supervision team, local colleges and universities should make the following improvements. First, they should adjust the previous selection scheme of teaching supervisors. Apart from the complete part-time retired professors who have strong ability in teaching as well as rich experience in teaching management and industry-study-research with high level, they should also add some full-time teaching supervisors between the age of 35 to 50 who have both high degree and rich teaching experience, and meanwhile they can adjust themselves to new trend by absorbing new ideas, new opinions and new methods constantly to guide the supervision work. Second, pre-job training and on-job study should be implemented for teaching supervisors in colleges and universities to promote their qualities. As for the teaching management, it will be terrible if supervisors' qualities lag behind teachers' professional levels. While guiding teachers' professional development, supervisors should also pay attention to their own improvement by further study so as to set good examples for teachers, and then teachers can understand improvement of their qualities is part of professional life. The pre-job training means systematic training on teaching supervisors for their weaknesses, such as pedagogy knowledge. As for on-job study, it means that teaching supervisors should investigate and study in cooperative schools or units with timely discussion, communication, exploration and summary of problems they encounter so as to achieve a common improvement. Third, a supervision institute of students' information should be established so as to give full play to students' initiative and activeness in participating in school teaching and management. University students are direct objects and beneficiaries of higher education, and they can directly feel the teaching and management in their school. To select some excellent and fair university students with compassion, service consciousness and strong learning capability is not only the major content of teaching supervision team building, but it is also beneficial trial and complement of teaching supervision work in colleges and universities.

\section{ACKNOWLEDGMENT}

Hunan Province 2015 Regular Institutions of Higher Education Teaching Reform Project(Xiang Jiao Tong[2015]291)-“The theory and practice research of transitional development in local colleges and universities--take Xiangnan University as example ”, “A study on the construction of double qualified teachers team in the local Universities based on the cooperation between Universities and enterprises"

\section{REFERENCES}

[1] Decisions on Accelerating the Development of Modern Vocational Education issued by the State Council. Xinhua,June 22, 2014.

[2] Applied Technique-Oriented Universities League. Transition and Development Research Center of Local Colleges and Universities. Report on Transition Development Practice and Policy Study of Local Colleges and Universities. 2013, 13.

[3] Kong Fanmin, Guo Shumin, Tang Xiaoheng, et al. Ways to Build Applied Universities. The first version [M]. Beijing: Beijing Student Press, 2006, 47-50.

[4] Stufflebeam. Scheme Evaluation on CIPP Mode. Translated by Chen Yukun Beijing:People's Education Press, 1989:298

[5] Yu Xiaopo. Problems in Supervision of Teaching Quality in Contemporary Colleges and Universities As Well As Countermeasure $[\mathrm{J}]$. Evaluation on Chinese Higher Education, 2001, (2), 58-59

[6] He Yuling, Yuan Guilin. Characteristic and Reforming Tendency of American Educational Supervision[J].Foreign Education Study, 2008, (10), 42

[7] Qian Yicheng. Study on Foreign Education Supervision and Evaluation System[M]. Beijing: Press of China Central Radio \& TV University, 2006, 222-223

[8] Illich, I. "Deschooling Society". New York: Harper and Row, 1970 .

[9] Edgar Morin, translated by Chen YiZhuang. "Complexity theory and education". Beijing: Peking University Press,2004,pp43.

[10] Yang Zhongkai, Liu Yongzhen. "From simplicity to complexity". System dialectics report,2002,pp47. 